\title{
Introduction: Religion and Violence, Rights and Reconciliation
}

\author{
Daniel H. Levine
}

check for

updates

Citation: Levine, Daniel H. 2021. Introduction: Religion and Violence, Rights and Reconciliation. Religions 12: 134. https://doi.org/ 10.3390/rel12020134

Received: 18 January 2021

Accepted: 17 February 2021

Published: 20 February 2021

Publisher's Note: MDPI stays neutral with regard to jurisdictional claims in published maps and institutional affiliations.

Copyright: (C) 2021 by the author. Licensee MDPI, Basel, Switzerland. This article is an open access article distributed under the terms and conditions of the Creative Commons Attribution (CC BY) license (https:/ / creativecommons.org/licenses/by/ $4.0 /)$.
Department of Political Science, University of Michigan, Ann Arbor, MI 48109, USA; dhldylan@umich.edu

Planning for this Special Issue began in late 2019, well before the COVID-19 pandemic changed the conditions of life for all of us. I want to begin by thanking the contributors and the editors of the journal for working under difficult conditions to help make this issue a reality. The papers presented here shed important and varied light on the continuing relations of religion and violence, rights and the possibilities of reconciliation. The data and reflections offered in these six papers are grounded in contemporary and historical reality, working with a rich range of information from archival and documentary sources, and from contemporary interviews and observations. The papers work with materials from Latin America, an area that presents scholars and observers with a reality that has undergone dramatic changes over the last half-century, as both religion and politics have changed in fundamental ways. Throughout this period, the relations among religion and violence have remained prominent in the public sphere, where religiously linked and inspired activism around issues of human rights have contributed to reshaping the terms of public debate.

The primary materials presented here may be from Latin America, but the issues are general. What we see in Latin America is not unique: these experiences are echoed across a wide range of cultures, religious traditions, and historical eras. Religious individuals, groups and institutions have been victims and perpetrators of violence. They have rallied to action (including protests, civil conflicts, and wars) to engage with opposing religions, to support or oppose existing states and social orders, or to advance or enforce policy agendas. These actions have at times been impelled by religious leadership to support or oppose existing states and social orders. The influence is never just one way: political or dynastic authorities of all kinds have also reached out to religions, mobilizing them for support and legitimization, but also working to suppress or marginalize.

The 20th century has also witnessed a surge of movements that advance and articulate organizational nets intended to justify and defend human rights. The concept of rights draws on civil law and religious tradition, with important links to religious organization networks and resources. The root concept is that if all humans are children of God, made in the image of God and of intrinsic value, then all are entitled to life. Religious ideas and networks were especially important in the civil rights movement in the US, and have been prominent in recent Latin American experience. These ideas have also inspired important efforts in post-violence reckoning and reconciliation, for example in the experience of truth commissions, and efforts to identify victims, and in this way they allow survivors and families to grieve.

Attention to the mutual impacts of religion and violence should not obscure lengthy traditions of non-violence, with roots in core religious ideas. Non-violence is both a personal and group belief, and also a tactic for opposing state power. Notable modern instances of non-violence as a commitment and tactic include the U.S. civil rights movement (grounded in the African American churches), the Indian experience of non-violent resistance inspired by Gandhi, peace and rights activists in the last days of the East German communist regime, and the anti-apartheid movement in South Africa. Pacifists like Quakers and Mennonites, and group such as Witness for Peace, also provide mediation and neutral spaces for conflict resolution. They have often been present at areas of intense conflict throughout the region. Priests and sisters in Peru trying to maintain a presence 
in areas of severe violence took active training in non-violence. As these brief comments suggest, no single direction or model can make sense of the tangled relations between religion and violence, rights and reconciliation. The papers in this issue shed new light on these realities from a variety of perspectives.

Cecilia Tovar of the Instituto Bartolomé De Las Casas, Lima, Peru, documents how and why the churches came to take up the defense of human rights in Peru. During the war with Shining Path (1980-2000), violence in Peru was brutal and extensive. Massive violations of human rights were common, with victims from all regions and social classes, but were particularly intense in rural areas where the insurgency began. The choice to defend human rights in theory and in action is rooted in transformations within the church, which drew strength and inspiration from the "option for the poor", articulated at the Catholic bishops meetings in Medellin (1968) and Puebla (1979), and in numerous statements and organizational efforts since then. Those churches who identified more closely with the poor were more active in the promotion of rights. The churches supported and defended rights by providing organizational space, legal defense, publicity (through their radio networks), and by remaining among populations in danger, working with them and often sharing their fate. Important elements in the churches, including leaders, priests, members of religious orders, sisters, catechists, and ordinary people working through church organizations, were prominent among the victims. They were attacked both by Shining Path (who saw them as competitors) and by army and police forces, who saw their commitment to social justice and collective action as subversive. Professor Tovar works with a wealth of documentation at the national, regional and local level: reports from the Peruvian Commission for Truth and Reconciliation and others from the Peruvian Catholic Church, as well as from regional and local groups.

Maria Soledad Catoggio of CEIL Conicit, Argentina, looks closely at a remarkable facet of the post-violence reconciliation in Argentina. Her research examines in detail the multiple links between the Argentine Forensic Anthropology Team (Equipo Argentino de Antropología Forense (EAAF)) and the world of religion. The EAAF worked over-time to recover and identify victims of repression by the last military regime. Catoggio defines this as "forensic activism", set in motion and advanced outside the state, and independent of both the human rights movements and the national system of universities and research centers. This kind of work brought the living and the dead together, by making it possible for families and relatives of the dead to engage in mourning rituals that situate and make sense of suffering. Religious beliefs and the tools they offer for coming to terms with grief coexisted with the EAAF's development. These findings emerge from a qualitative research design combining document analysis, in-depth interviews, and the participative observation of scientific disclosure open to the public, provided by the EAAF over the past three years.

Stephan Ruderer of the Institute of Historical Studies of the Catholic University of Chile sheds new light on the politics of religion during the dictatorship of Augusto Pinochet (1973-1990) in Chile. Much historiography has examined this relation from the point of view of the Catholic Church, which took a prominent role in opposing the dictatorship, defending victims, and promoting human rights and a return to democracy. Professor Ruderer expands this view. Working with archival materials from the Chilean Foreign Ministry and correspondence with the Chilean ambassador to the Vatican, he examines in detail efforts by the Chilean state to shape relations with the Church and to change the position of bishops who were critical of the regime. After a short period of accommodation and legitimization, the Chilean episcopate started to confront the dictatorship in the name of the poor and persecuted, but never breaking entirely with the regime. This led to a complicated relationship between the Church and the dictatorship, which tried to legitimize authoritarian rule by reference to Christian values and the defense of "Christian civilization." Examining the relations from this point of view helps us understand better the dynamics of conflict between Church and State in Chile during the dictatorship: this was a continuous relation of conflict, accommodation, and on-going efforts to shape reality. 
Silke Hensel of the University of Muenster, Germany, works with a wealth of archival data to re-examine the history of church-state disputes and often violent religious conflicts, which were a central axis of political conflict in early 19th century Mexico. Church-state disputes often hinged on questions of legal status, rights, and property. Conflicts over the proper role of religion in society and culture touched on valued symbols and routines of daily life, and often involved significant violence. Global histories commonly attribute conflicts surrounding the secularization of the state exclusively to Europe, but in fact such disputes have long been an important thread in Latin America in general, and in notable cases, like Colombia or Mexico, where issues about the role of religion and the church in society became a major political conflict after independence. Best known in the Mexican case are the disputes over the constitution of 1857, which established the freedom of religion, and the Cristero Revolt in the 1920s. However, the history of struggles over the separation of church and state and the secularization of society goes back further. In 1835, the First Republic ultimately failed, because of the massive protests against the anticlerical laws of the government, which were motivated by people seeing the social order as a whole threatened by what they considered to be anti-religious measures. Hensel shows that the failure of the first government system of republican Mexico was not only due to struggles between federalists and centralists or conservatives and liberals, but also came about because political and religious conflicts became intertwined, and many Mexicans engaged in the struggles over the appropriate social order.

Hensel shows that this failure is understood as a genuine religious conflict over the question of the proper social and political order, in which large sections of the population were involved. Beginning with the anticlerical laws of 1833, political and religious reaction in Mexico often began with a pronunciamiento (a mixture of rebellion and petitioning the authorities), and evolved into conflicts over federalism vs. centralism.

Virginia Garrard, University of Texas, brings us to the present, which, in Latin America, has been profoundly marked by a notable surge of Evangelical and Pentecostal Protestantism throughout the region. Historically, Evangelical and Protestant churches in Latin America regarded the "world" as a realm of sin and impurity. The proper focus of the church, they believed, was on salvation, and building a community of the saved. However, this has begun to change with a new engagement by the churches in society and politics as part of an effort to create a better world. Important elements of this movement have found inspiration in Dominion Theology, a long covert movement that works to bring conservative Christians to political power in order to affect "dominion" over the earth, and thus hasten the Kingdom of God. Many Dominionists belong to NAR (New Apostolic Reformation), a loose network of "apostles" with a large popular following, given their presence in megachurches or as televangelists. Although its origins are in the United States, this is a global movement, hidden in plain sight, with an important presence in Latin America, notably in Guatemala and Brazil. The movement is much contested within Latin American Protestantism, but its advocates already have a visible presence and major political allies. They are committed to waging "spiritual warfare" so as to cleanse what they see as tainted people and societies. This commitment has contributed to an upswing in violence related to religious intolerance

Danielle Boaz, of the University of North Carolina, Charlotte, takes the theme of religiously linked violence in a new direction. She shows that since at least 2005, drug traffickers in the cities and favelas of Rio de Janeiro have been carrying out systematic and violent assaults on Afro-Brazilian religious communities. Motivated by their conversion to sects of Evangelical Christianity that regard Afro-Brazilian religion as devil worship, these gangs of traffickers have forcibly expelled devotees of these faiths from their homes and temples, destroyed shrines and places of worship, and threatened priests with death if they continue to practice their religion. Boaz argues that a stress on "spiritual warfare" is not the best approach for making sense of this phenomenon. She advances a thesis grounded in the defense of human rights. In her view, this is not a two-sided struggle between Evangelized drug traffickers and Afro-Brazilian religions. Rather, the former is 
unilaterally committing gross violations of the latter's human rights, which contravene international norms prohibiting crimes against humanity and genocide. This rich and innovative analysis demonstrates how profoundly the whole field of religion, society and politics is changing.

The wide-ranging papers gathered in this issue show clearly that the old Enlightenment dream that religion would simply fade away needs to be reconsidered. This dream took a sociological form in conventional secularization theory, which has proven at the very least to be a poor guide to the realities of religion, society and culture, which remain dynamic and ever-changing. The prominence of violence may and likely will fade, but religious institutions, groups, norms and values will continue to shape the reality of our world.

Funding: This research received no external funding.

Conflicts of Interest: The author declares no conflict of interest. 